\title{
Kampung Wisata Adat Batak Toba
}

\author{
Ayubbi Oentoro V dan Totok Noerwasito \\ Departemen Arsitektur, Fakultas Arsitektur Desain dan Perencanaan, Institut Teknologi Sepuluh Nopember (ITS) \\ e-mail: vitonoer@arch.its.ac.id
}

\begin{abstract}
Abstrak-Di era perkembangan zaman yang semakin maju kita sebagai warga negara Indonesia seakan-akan kita lupa dengan seni dan budaya yang kita miliki. Bahkan dalam dunia arsitektur. Arsitektur Nusantara lebih dikenal dengan bangunan primitif bagi manusia modern. Dengan adanya perbedaan primitif dan modern maka arsitektur Nusantara semakin tidak terlihat keberadaannya, dan teknologi arsitekturalnya akan semakin hilang ilmunya. Seharusnya kita, warga negara Indonesia bangga dengan seni dan budaya kita yang sangat kaya, dengan memperkenalkan seni dan budaya kita di era perkembangan zaman modern ini. Berdasarkan dari berbagai permasalahan di atas antara mengkini dan primitif munculah sebuah ide respon mengkombinasikan kedua jenis bangunan tersebut. Kampung Wisata Adat Batak Toba akan menghadirkan kampung asli Batak Toba dengan bangunan primitif dan bangunan yang mengkinikan arsitektur Nusantara sesuai dengan kebutuhan manusia modern sekarang, dan tidak lupa tetap menghadirkan bangunan asli Batak Toba (Ruma Bolon) sebagai tempat tinggal dan rumah penduduk sekitar. Perancangan desain menggunakan metode charles jencks, dimana pengkombinasian antara arsitektur tradisional dengan arsitektur modern yang harus memenuhi beberapa unsur, seperti aspek warna, aspek dekorasi, dan aspek masa lalu. Konsep dari kampung wisata ini adalah mempertahankan keaslian, mengkombinasikan teknologi lama dengan yang baru, dan adanya kebutuhan zoning pada lahan.
\end{abstract}

Kata Kunci-Batak Toba, Kampung Wisata Adat, Kombinasi Tradisional Dengan Terkini, Amnesia, Pelestarian.

\section{PENDAHULUAN}

I NDONESIA merupakan negara yang kaya akan seni dan budaya. Seni dan budaya mempengaruhi dalam kehidupan sosial, kebiasaan, cara berpakaian, dan berpengaruh ke nilai arsitekturalnya. Setiap daerah di Indonesia memiliki sifat tersebut dengan cara merespon yang berbeda-beda sesuai dengan kondisi yang mereka miliki. Kita sebagai generasi penerus seperti tidak tahu menahu tentang semua kekayaan itu, karena perbedaan zaman yang semakin maju. Perkembangan zaman menyeret kita ke arus yang serba instan dan seakan-akan membuat budaya baru, perkembangan zaman mempengaruhi dalam segi aspek kehidupan sosial, kebiasaan, cara berpakaian, dan ke nilai arsitekturalnya. Perkembangan zaman dipengaruhi oleh budaya luar yang berhasil mempengaruhi semua aspek tadi di Indonesia.

Dibangunnya kembali rumah adat Batak Toba yang telah terbakar (Gambar 1) dengan dijadikannya desa wisata memiliki peluang melestarikan, memperkenalkan, dan belajar Arsitektur Nusantara. Dengan adanya desa wisata bisa membantu warga Jangga Dolok untuk mendapatkan penghasilan ekonomi dan wawasan tentang dunia luar, dengan adanya timbul sosialisasi antara wisatawan dan warga Jangga

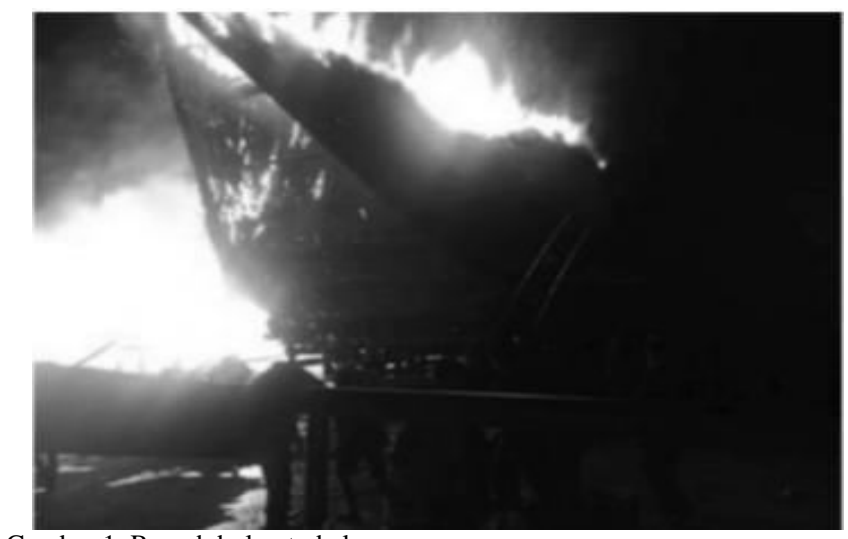

Gambar 1. Rumah bolon terbakar.

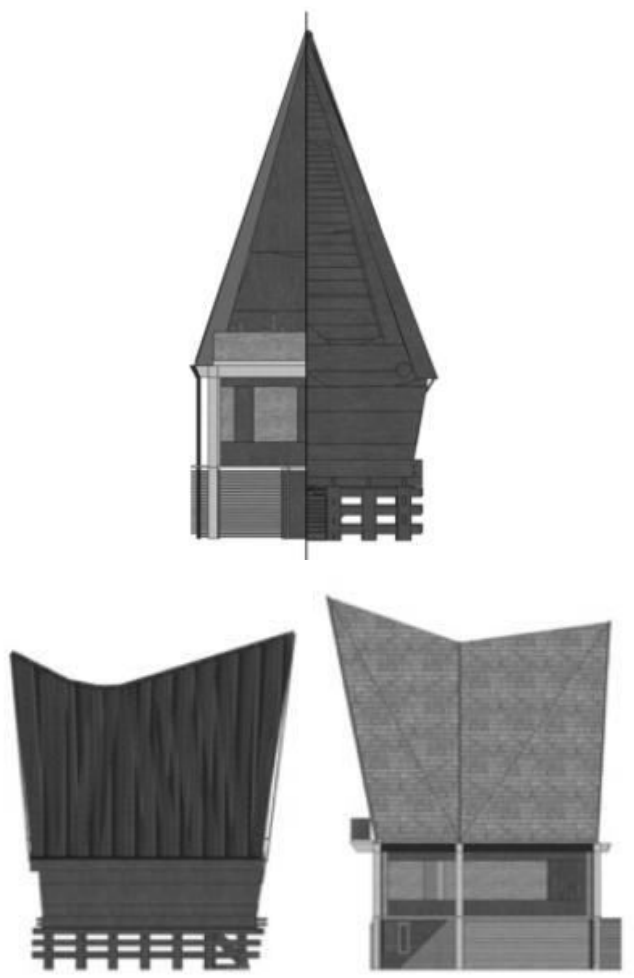

Gambar 2. Desain bentuk.

Dolok. Dengan dijadikannya kampung wisata adat akan timbul ketertarikan dari warga Indonesia untuk datang, belajar, dan memperdalam ilmu tentang arsitektur Nusantara beserta budayanya.

Pembangunan desa wisata adat ini akan mengangkat nilanilai dan unsur-unsur asli rumah adat Batak Toba dan mengambil nilai-nilai dan aspek-aspek bangunan mengkini. Dengan adanya unsur modern yang di transformasikan dan 

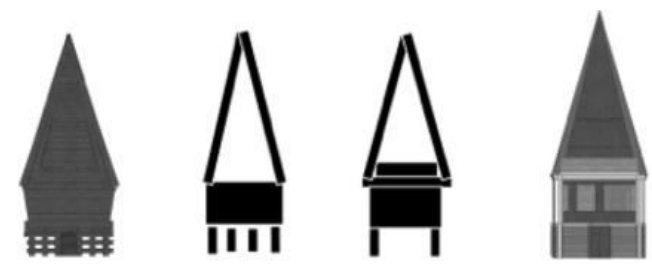

Gambar 3. Transformasi bentuk.
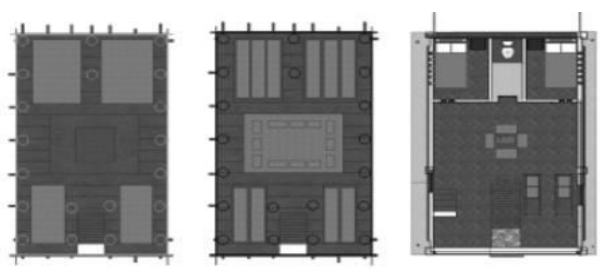

Gambar 4. Denah bangunan.

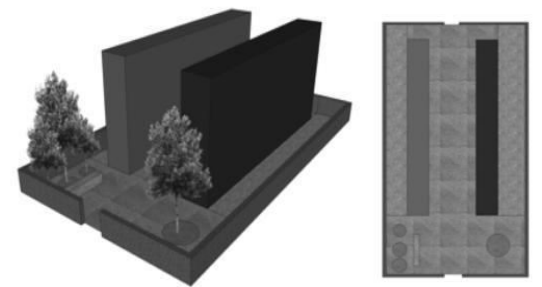

Gambar 5. Kampung Batak Toba.

Gambar 6. Site plan.
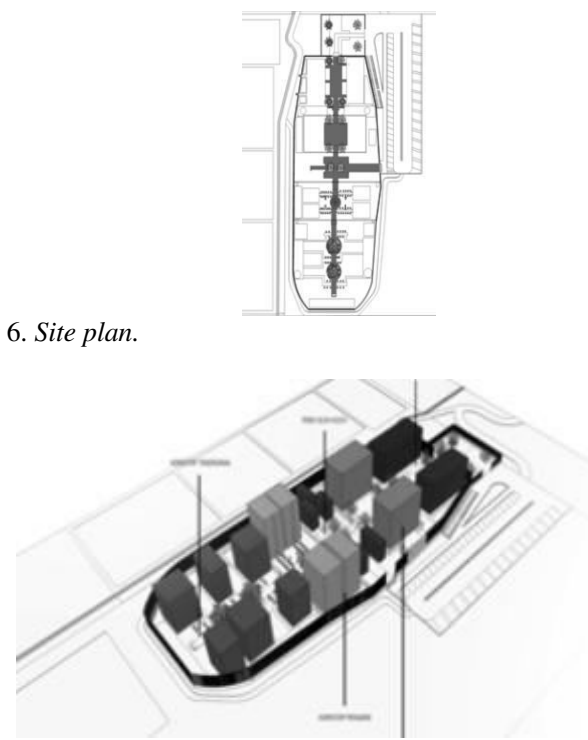

Gambar 7. Zoning dan tatanan massa.

dimodifikasi antara gagasan modern dengan gagasan arsitektur klasik untuk mencapai suatu karya arsitektur yang berciri Nusantara disini, Arsitektur Nusantara dapat di globalkan (memodernkan arsitektur Indonesia) [1].

\section{METODE PERANCANGAN}

Di dalam merancang proses merancang suatu objek terdapat berbagai macam cara untuk memulai proses merancang, salah satu cara yang di gunakan seperti merancang dengan melakukan pendekatan utama terhadap konsep dbangunan lama. dapat dirasakan seperti karakter bangunan tradisional, pada intinya purna modern berusaha menghadirkan yang

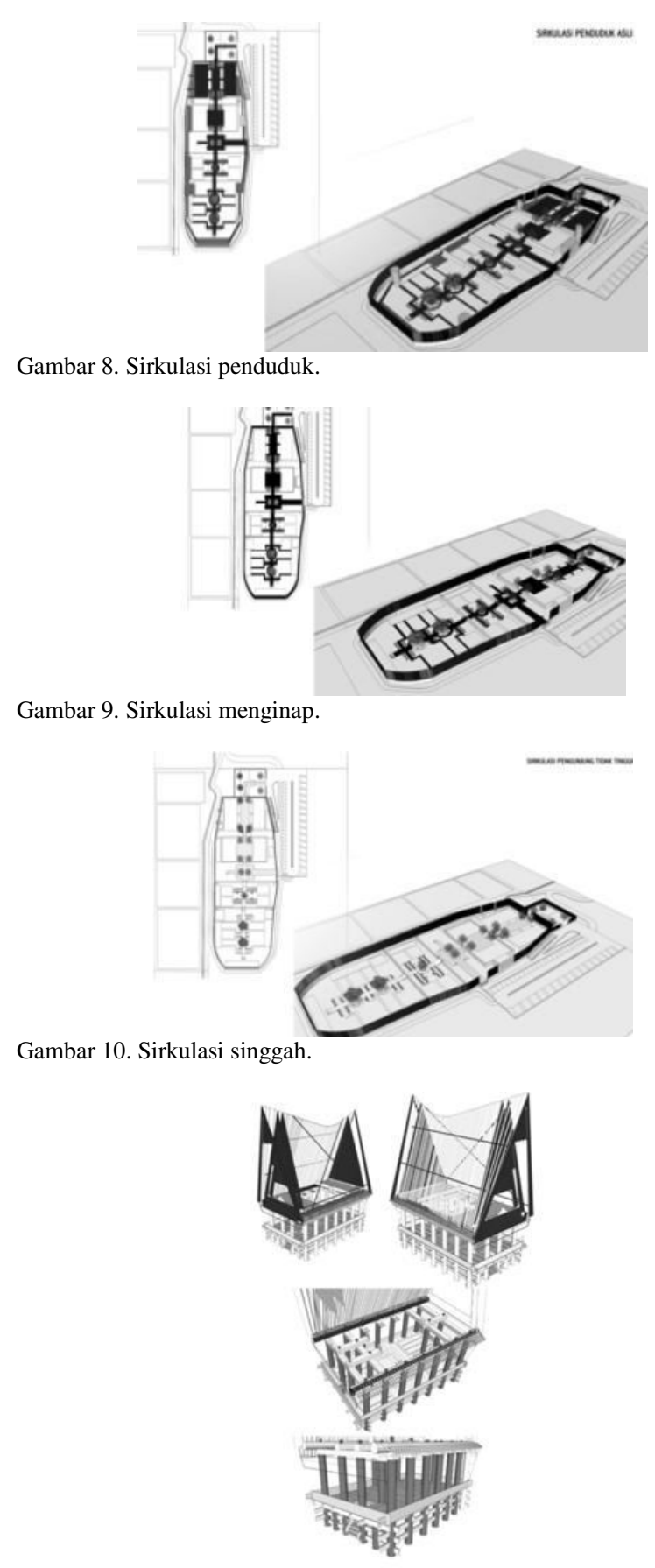

Gambar 11. Struktur tradisional.

Tradisional adalah sikap dan cara berfikir serta bertindak yang selalu berpegang pada norma dan adat yang ada secara turun temurun. Tradisional berasal dari kata "tradisi" artinya adat kebiasaan turun temurun yang masih dijalankan oleh kelompok masyarakat. Tradisionalism adalah suatu paham yang berdasarkan pada tradisi .

Rayner Banham pada bukunya yang berjudul "Age of The Master: A Personal View of Modern Architecture", 1978, perkembanagan arsitektur modern menekankan pada kesederhanaan suatu desain. Para arsitek pada masa itu menginginkan bangunan rancangannya bersih dari ornamen dan sesuai dengan fungsinya [2]. 

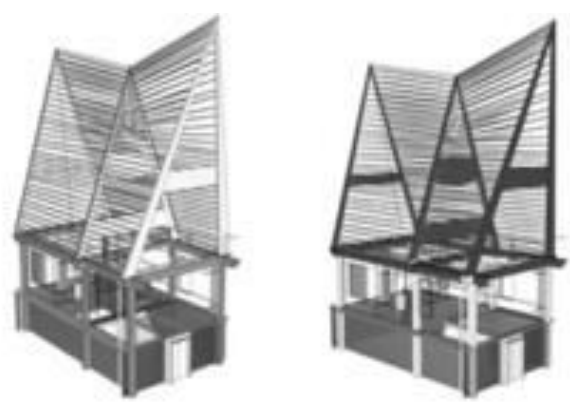

Gambar 12. Struktur modern.

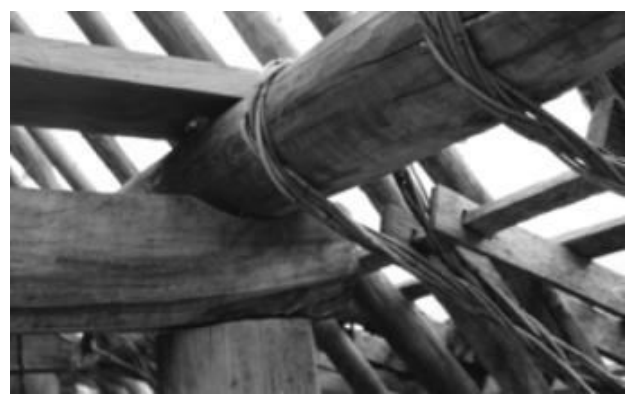

Gambar 13. Kayu nangka.

Arsitektur Tradisional Modern adalah perkembangan secara bertahap dari arsitektur purna modern (postmodern). Bangunan tradisional tetap lama dalam bentuk universal ada beberapa unsur yang dirangkum untuk mendesain, unsur perancangan pada bangunan kampung ini menggunakan kebutuhan hirarki: Maslow Hierarchy of Needs, untuk menyesuaikan kebutuhan manusia yang akan dimasukan pada perancangan, dan pendekatan desain Jarak Sosial adalah Jarak Fisik. Bangunan akan dibuat untuk mendekatkan pengguna satu dengan pengguna yang lainnya, adanya konsep pada bangunan tidak adanya kesenjangan sosial antara pengguna dan penduduk sekitar.

\section{HASIL DAN EKSPLORASI}

\section{A. Konsep Bentuk}

Bentuk bangunan diambil dari bentuk asli rumah adat Batak Toba (gambar 2), kampung wisata akan menonjolkan unsurunsur keaslian rumah adat Batak Toba untuk mengingatkan kembali dan memperkenalkan rumah adat Batak Toba [3]. Beberapa bangunan dipadukan dengan teknologi kebutuhan manusia modern untuk dapat menempati bangunan yang dikinikan. Bangunan yang dikinikan tetap mempertahankan bentuk dan unsur bangunan lama untuk mempertahankan image unsur keasliannya [4]. (Gambar 3)

\section{B. Konsep Denah}

Denah bangunan pada rumah penduduk dan tempat inap pengunjung memiliki sedikit transformasi bentuk dan fungsi ruangannya, rumah adat memiliki 4 ruang didalam bangunannya yaitu untuk beristirahat tanpa sekat, dan ditengah terdapat tungku untuk memasak dan mengahangatkan tubuh [3], pada bangunan tempat inap pengunjung tradisional masih mempertahankan 4 ruang tidur, tetapi menghilangkan fungsi tungku diganti dengan tempat

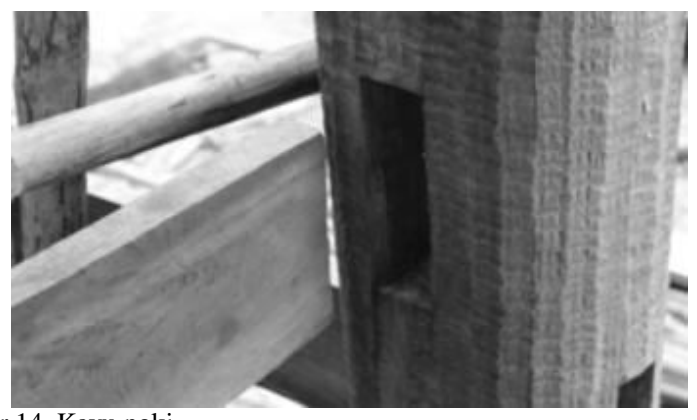

Gambar 14. Kayu poki.

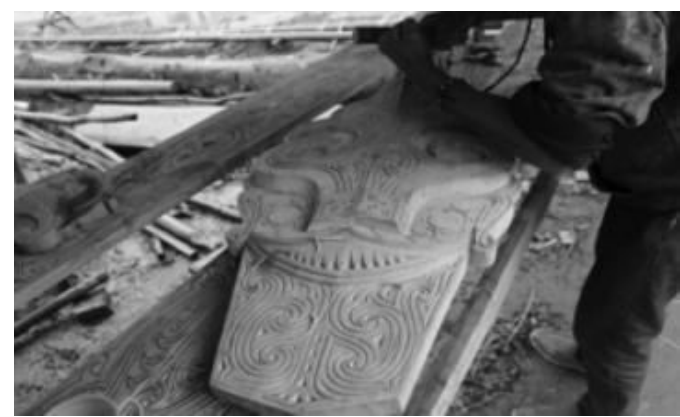

Gambar 15. Kayu ulin.

untuk berkumpul dan untuk makan, pada bangunan inap yang dikinikan, menggunakan 2 ruang untuk tidur, toilet didalam bangunan dan ruang tengah digunakan untuk dapur kecil, pada bangunan ini menggunakan sekat untuk kebutuhan privasi dari penghuninya (Gambar 4).

\section{Konsep Kampung}

Kampung Batak Toba hanya memiliki satu jalur yang ditengahnya merupakan jalur utama dihimpit berhadapan oleh rumah dan sopo, kampung batak memiliki 2 pintu gerbang yaitu bagian depan (harbangan) dan belakang (Harbangan Pudi), kampung Batak Toba dikelilingi oleh batu kali dan pohon bambu, selain itu kampung Batak Toba pada pintu gerbang depannya terdapat pohon nangka, tempat menumbuk padi seisi kampung, dan partungkoan dari pohon beringin [3]. (Gambar 5)

\section{Konsep Zoning dan Tatanan Massa}

Zoning pada bangunan dibedakan menjadi 5, yaitu: rumah penduduk (hitam), rumah tetua adat (biru), pusat perbelanjaan souvenir (ungu), tempat tinggal bangunan yang dikinikan (hijau), dan tempat tinggal bangunan tradisional (coklat muda) (Gambar 7). Rumah penduduk berada didepan untuk menjamu para tamu yang dateng untuk berwisata, dengan adanya posisi rumah penduduk didepan maka para tamu akan langsung berhubungan dengan penduduk. Tatanan masa dibuat agar memiliki hubungan harmonisasi dengan pengguna kampung ini [5].

\section{E. Konsep Sirkulasi}

Sirkulasi dibagi menjadi beberapa kebutuhan kampung wisata ini, yaitu :

a. Sirkulasi penduduk, penduduk memiliki kebutuhan seperti berkebun, dan beternak. Sirkulasi penduduk untuk melakukan kegiatan berkebun dan 


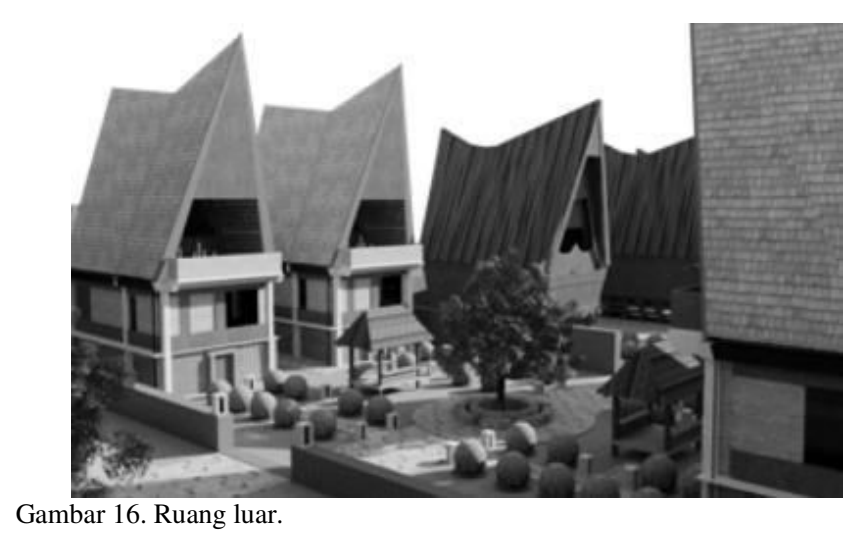

beternak berada dibelakang bangunan sehingga tidak menghalangi para wisatawan yang datang. Tetapi dikampung ini tetap menjaga keaslian dari bagaimana cara penduduk asli melakukan kegiatan. (Gambar 8)

b. sirkulasi pengunjung yang menginap, pengunjung yang menginap memiliki sirkulasi yang dapat mencakup semua tempat wisata didalam kampung ini. Selain untuk melihat tempat wisata rumah adat pengunjung dapat tinggal dirumah yang sudah disediakan pada kampung wisata ini. (Gambar 9)

c. sirkulasi pengunjung untuk berwisata. Pengunjung yang berwisata mempunya sirkulasi yang paling kecil lingkupnya karena memiliki kegiatan bersinggah dan melihat-lihat sekitar kampung. (Gambar 10)

\section{F. Konsep struktur}

Atap bangunan mengunakan sistem struktur tanpa kudakuda dimana segitiga-segitiga bangunan pada atap menopang struktur atap sehingga tidak menggunakan kuda-kuda pada bangunan modern sekarang ini. Atap dan badan bangunan rumah tradisional Batak Toba bisa dipisah, karena tidak menggunakan struktur mati. (Gambar 11)

Badan bangunan menggunakan sistem struktur tiang yang meruang, setiap tiang di kunci dengan kayu horisontal sehingga kuat untuk menahan bangunan.

Atap struktur bangunan modern sedikit mengambil konsep bangunan aslinya, yaitu struktur atap meruang tanpa kudakuda. Atap dimodifikasi menggunakan rangka baja dan atap genteng, segitiga atap masih dimanfaatkan untuk menopang beban atap. Atap bisa di pisah dengan badan rumah karena menggunakan konsep bangunan lama. Atap dan badan dipisah untuk mempermudah dalam proses perancangan.

Struktur badan bangunan modern menggunakan konstruksi beton dan baja sebagai penopang bangunan. (Gambar 12)

\section{G. Struktur}

Kayu Pinasa (nangka), tiang untuk menopang beban atap. Melintang horisontal bangunan. Kayu ini memiliki sifat yang kokoh, dan pada batangnya berwarna kuning. (Gambar 13) Kayu Poki (kayu keras), digunakan untuk tiang utama badan bangunan. Kayu ini memiliki sifat yang kokoh dan kuat sehingga digunakan sebagai konstruksi utama. (Gambar 14) Kayu Ulin, digunakan untuk membuat ukiran pada bangunan. Kayu ini memiliki sifat keras, tetapi memiliki tekstur yang lembut pada serat kayunya sehingga mudah untuk diukir. (Gambar 15)

\section{H. Konsep Ruang Luar}

Ruang luar memiliki fungsi untuk mengikat massa antar pengguna ruang luar menggunakan konsep dari kampung aslinya tapi dipadukan dengan kebutuhan sekarang, dengan adanya desain ruang luar yang memiliki ke identikan dengan massa, maka ruang luar berfungsi untuk menyatukan dari beberapa zoning yang didesain pada kampung. Ruang luar menggunakan konsep lama yaitu menggunakan kursi batu dan pohon sebagai naungan. Zaman dulu kursi batu ini digunakan sebagai rapat untuk membahas suatu masalah atau pesta mengenai adat. Pada kampung wisata ini tempat duduk dikombinasikan dan dipadu dengan teknologi dan memperhatikan nilai estetika dan fungsi sebagai ruang luar untuk berkumpul. (Gambar 16)

\section{KESIMPULAN}

Mendesain Kampung Wisata Batak Toba merupakan objek arsitektural yang merespon isu tenggelamnya arsitektur Nusantara, dan budaya Indonesia karena perkembangan zaman, dan mendesain kampung wisata adat yang tanggap atas kebutuhan manusia modern.

Bentuk pola kampung asli dikombinasikan dengan sentuhan modern akan memberikan ketertarikan kembali kepada kampung ini, ditambah dengan kombinasi rumah adat dengan teknologi modern untuk menampung kegiatan dan aktifitas yang menyesuaikan kebutuhan manusia modern.

Mendesain bangunan dengan memanusiakan manusia dan mempertahankan adat istiadat setempat akan memberikan pengalaman baru dan pandangan baru tentang bangunan adat. Desain ini dirasa mamp u menjawab permasalahan dari lupa akan budaya Batak Toba, hilangnya ilmu arsitektur Nusantara Batak Toba, dan budaya setempat. Desain kampung ini nantinya akan mampu menarik masyarakat untuk datang, beraktifitas saling berinteraksi, dan kebutuhan rekreasi dan edukasi.

Kampung wisata ini memiliki kelompok zoning pada site, yaitu tempat untuk penduduk sekitar, tempat untuk kepala adat yang dituakan, tempat perbelanjaan, tempat penginapan yang dikinikan, dan tempat penginapan tradisional. Adanya pembagian zoning pada lahan karena disesuaikan dengan kebutuhan penggunanya.

Dengan adanya kampung ini diharapkan akan kembali diingatkan bentuk pola kampung, dan rumah adat dengan unsur-unsur keaslian dari berbagai macam corak, material, teknologi, budaya, dan kebiasaan sehari-hari penduduk.

Kampung wisata adat tetap memperhatikan kebiasaan dari penduduk sekitar dalam hal berkebun dan beternak, kampung wisata ini menyajikan keaslian dari unsur rumah, unsur kampung, unsur budaya, dan unsur kebiasaan sehari-hari dari penduduk sekitar.

Kampung Wisata Batak Toba ini akan menghilangkan pola pikir antar arsitektur primitif dan arsitektur mengkini yang memiliki kesenjangan yang sangat jauh. Dengan adanya kampung ini teknologi modern dan teknologi primitif akan dikombinasikan dan menjadikan bangunan yang harmonis. 
DAFTAR PUSTAKA

[1] J. Prijotomo, "Prijotomo Benahi Arsitektur Nusantara," Surabaya, 2017.

[2] R. Banham, Age of The Master: A Personal View of Modern Architecture. Harper And Row, 1975.

[3] G. Rajamarpodang, "Dalihan Na Tolu Nilai Budaya Suku Batak,"
Medan, 1992.

[4] C. Jencks, Languange of Post Modern Architecture. Academy editions, 1977

[5] W. Rob, Social Distance, in Action. Journal of Archeological Method and Theory. Springer, 2016. 